\title{
Entreprenørskab og læringsmål
}

\author{
Helle Munkholm Davidsen, docent, ph.d., Center for Anvendt \\ Skoleforskning, UC Lillebælt. heda@ucl.dk
}

\begin{abstract}
Resumé
Artiklen beskriver et Design-Based-Research studie, som har undersøgt, om det er muligt at forene arbejdet med entreprenøriel læring og læringsmål i folkeskolen. Studiet er baseret på en forståelse af entreprenørskab som en kompetence, der udvikler elevernes autonomi og personlige engagement via læringsmuligheder. Det har været hensigten at undersøge, om denne form for entreprenøriel læring kan forenes med læremålstyret undervisning. Studiet har også som formål at undersøge, om motivation for læring fremmes via en entreprenøriel tilgang, der fokuserer på differentieringsmuligheder og medbestemmelse. I artiklen beskrives den teoretiske baggrund for entreprenøriel læring, udviklingen af prototyper, særligt i forhold til arbejdet med at formulere læringsmål, og studiets centrale fund. Studiet viser, at en differentieret tilgang til læringsmål (i form af flere valgmuligheder) styrker elevernes personlige engagement i undervisningen, men det viser samtidigt, at læringsmål i sig selv som entydige mål fremmedgør læringen for eleverne. Studiet peger desuden på, at eleverne i udgangspunktet er frakoblet læring på et personligt niveau, da de anskuer læring som lærerens projekt. Endelig dokumenterer studiet, at det helt overordnet er særdeles vanskeligt at arbejde med læringsmål på en måde, som er meningsfuld for eleverne. Dette studie peger således på, at læringsmål ikke er vejen til at styrke elevernes autonomi, og afkræfter derfor i en vis forstand, at entreprenøriel læring kan forenes med læringsmål. Resultatet er imidlertid ikke, at man skal opgive at arbejde med læringsmål, men rejser spørgsmålet om, på hvilken måde det er mest hensigtsmæssigt at arbejde med læringsmål.
\end{abstract}

\section{Nøgleord}

Entreprenørskab, læringsmål, entreprenøriel læring, differentiering og medbestemmelse

\section{Artikel inden for tema. Fagfællebedømt}




\section{Introduktion}

Innovation og entreprenørskab er blevet et tværgående emne i Fælles Mål i forbindelse med den seneste revision af Fælles Mål i 2014. Innovation og entreprenørskab skal hermed både integreres i skolens fag, i den personlige udvikling og i værdiskabende projekter (Ministeriet for børn, undervisning og ligestilling, 2014c). Det er imidlertid ikke en uskyldig eller nem manøvre at integrere innovation og entreprenørskab i skolen. Der er ikke kun simpelt tale om, at fagene skal tilføjes en innovativ værdi, men om at skolen skal skabe rum og mulighed for elevernes entreprenørielle engagement i læring.

Forskning i entreprenørskab og entreprenørskabsuddannelse viser således, at entreprenørskab som personlig kompetence hænger tæt sammen med personlig autonomi, herunder muligheden for at vælge, for at handle selvstændigt og for at engagere sig personligt i sin egen læring (Bager et al., 2010; Blenker et al., 2012; van Gelderen, 2010; Davidsen, 2014; 2016). Dermed implicerer integrationen af innovation og entreprenørskab i skolen, at man skal styrke elevernes udvikling af personlig autonomi, deres mulighed for at tage personligt motiverede læringsvalg og deres mulighed for at forfølge egne ideer og læringsinteresser.

Det fordrer mere frihed til eleverne og en ny, udvidet måde at arbejde med fagene på. Begge dele udfordrer den gængse lærer- og målstyrede læringskultur. Denne artikel vil se nærmere på, om det er muligt at integrere det entreprenørielle krav om mere frihed til eleverne med læring i skolens fag ved at bruge læringsmål som en fælles pragmatisk ramme for differentiering og valgmuligheder.

Det valgte fokus på læringsmål er ikke begrundet læringsteoretisk (i en antagelse om, at læringsmål styrker læring) eller politisk (projektet blev formuleret parallelt med den nye vejledning til læringsmålstyret undervisning, som har skærpet læringsmålstyringen Undervisningsministeriet et al., 2014), men pragmatisk. Lærere har hele tiden skullet arbejde med læringsmål, og derfor udgør læringsmålene både et redskab til og en mulighed for, at lærere kan skabe en tydelig ramme, der i og med sin tydelighed og synlighed skaber rum og mulighed for mere valgfrihed til eleverne.

På baggrund af dette ræsonnement blev der i samarbejde med en gruppe af kollegaer ${ }^{1}$ udviklet et interventionsstudie, som, inspireret af Design-Ba1 Studiet er udført i samarbejde med Kirsten Bonde Sørensen, Nanna Klitø og Christoffer
Hjelm-Hansen. 
sed Research, udviklede og afprøvede prototyper på et didaktisk design, der synligt ekspliciterede en differentieret tilgang til læringsmål. Målet med studiet var at finde ud af, om en differentieret udfoldelse af læringsmål kunne styrke elevernes valgmuligheder og dermed deres autonomi.

I mange tilfælde er det imidlertid ikke nemt for lærere at arbejde eksplicit med læringsmål. Derfor blev det en central del af prototypeudviklingen at fremstille læringsmålene på en enkel, visuel og meningsfuld måde. Det var antagelsen, at synlige og meningsfulde læringsmål ville gøre det nemmere for lærerne at differentiere dem og dermed øge elevernes mulighed for medbestemmelse.

Projektet blev i overensstemmelse med Design-Based Research som kollaborativ forskningsmetode videreudviklet i samarbejde med og tilpasset den folkeskole, som indgik i studiet. Denne skole var særligt interesseret i at øge elevernes motivation for læring. Derfor blev det besluttet mere specifikt at undersøge, om en større grad af valgmuligheder kom til udtryk som øget motivation for læring hos eleverne. Elevernes øgede autonomi blev i studiet operationaliseret som medbestemmelse, da det var et begreb, som lærerne og skolen kunne relatere til. I og med at den synlige repræsentation af læringsmål stod centralt i projektet og i dets prototypeudvikling, blev effekten af dette også genstand for undersøgelse. Det rejste spørgsmålet, om visualisering i sig selv fremmer differentiering og medbestemmelse. Derudover undersøgte projektet, om et øget fokus på elevernes egen værdimæssige forståelse af læring påvirkede deres motivation for læring.

I det følgende vil studiet blive beskrevet med henblik på mere overordnet at belyse, hvad der påvirker elevernes autonome læringsengagement. Derudover vil der være et særligt fokus i fremstillingen og analysen af studiet på, hvad der er udfordringerne i arbejdet med læringsmål.

Artiklen indleder med en kort gennemgang af den metodiske ramme og det teoretiske grundlag for entreprenøriel læring, som hypoteserne i projektet hviler på. Det er dette teoretiske grundlag, der sammen med de specifikke forskningsspørgsmål udgør rammen for analysen af data fra projektet. Der foreligger tre typer af data fra studiet: visuelle collager (se mere om dem nedenfor), observationer fra undervisningen og lærerinterview. 


\section{Metodisk ramme: Interventionsstudie inspireret af Design-Based Research}

Studiet er et interventionsstudie, som er tilrettelagt inspireret af Design-Based Research (Amiel \& Reeves, 2008, s. 34). Disse to metodiske retninger blev forbundet, fordi studiet på den ene side, som et klassisk interventionsstudie, havde en række teoretiske hypoteser, som det ønskede at afprøve rigtigheden af i praksis. På den anden side blev disse hypoteser heuristisk tilpasset sammen med praksis som i et Design-Based Research-studie (Ejersbo et al., 2008, s. 150 f.). Studiet blev således videreudviklet i samarbejde med den skole som interventionen udførtes på, og tilpasset denne skole. Studiet ønsker overordnet, som et Design-Based Research studie, at skabe en stærkere forbindelse mellem teoretiske forskningsspørgsmål og praktiske udfordringer (Amiel \& Reeves, 2008, s. 34).

Endvidere er målet med praksistilknytningen i Design-Based Research at omsætte de teoretiske antagelser til prototyper, der bliver udviklet under hensyntagen til, hvad der virker i praksis, og hvad praksis er optaget af. Prototypeudviklingen var også en central del af dette projekt både som et metodisk værktøj (Ejersbo et al., 2008, s. 149) og som praksisudvikling.

Det er dog også et central element i Design-based Research, at prototypen afprøves i flere omgange og efter hver afprøvning evalueres og tilpasses efter evalueringen. I denne intervention blev der udviklet to prototyper på undervisningsforløb (et til dansk og et til matematik), som der kun var mulighed for at afprøve en gang. Erfaringerne fra den første prototype (forløbet i dansk) blev dog anvendt i udviklingen af den anden prototype (forløbet i matematik). Desuden blev de deltagende lærere inddraget i udviklingen af prototyperne for at gøre brug af deres praksiserfaring. Det var imidlertid vanskeligt for lærerne at bidrage i større omfang til prototypeudviklingen på grund af tidsmæssige vanskeligheder, og fordi det var vanskeligt for dem at arbejde med de nye forenklede fælles mål (som blev introduceret samtidig med dette studie). Prototypeudviklingen blev dog drøftet med lærerne og udviklet ud fra deres respons, og den bevirkede blandt andet, at prototypen blev udviklet mere detaljeret og mere instruktivt, end idéen var i udgangspunktet.

Hensigten i projektet er således overordnet, som nævnt, i overensstemmelse med Design-Based Research, da målet i sidste ende specifikt er at finde praktiske løsninger på, hvordan entreprenøriel læring kan udvikles i praksis indenfor rammerne af den nuværende skoleform. Det er hermed både praktisk og teoretisk interessant at afklare spørgsmål om sammenhæn- 
gen mellem læring og motivation i forhold til de tre variable, som studiet tester: visualisering, differentiering og medbestemmelse. Visualisering blev undersøgt, fordi det var antagelsen, at tydelige læringsmål havde betydning for lærerens tilbøjelighed til at give eleverne medbestemmelse og for elevernes mulighed for at engagere sig i læring. Medbestemmelse blev undersøgt som udtryk for, at eleverne opnåede øget autonomi, og differentiering blev undersøgt som udtryk for, at eleverne fik øgede valgmuligheder.

Både i forhold til den visuelle repræsentation af læringsmål og i forhold til at undersøge elevernes visuelle refleksion af læringsværdier inddrog studiet designforskningens opfattelse af visualisering som sprog og metode til både kommunikation, refleksion og adfærdsændring (Sibbet, 2013; Pallasma, 2009; Bamberger \& Schön, 1983). Det bygger desuden på forskningsresultater, som har vist, at deltagere i udviklingsforløb kan motiveres til at reflektere og ændre uhensigtsmæssige, dominerende værdier gennem visualisering (Sørensen, 2011; 2013a; 2013b).

Overordnet biddrager studiet samlet til at belyse spørgsmålet: hvordan kan man i praksis styrke elevers udvikling af personlig autonomi, særligt deres mulighed for at tage personligt motiverede læringsvalg? Som nævnt er spørgsmålet baseret på en teoretisk forståelse af entreprenørskab, som vil blive skitseret i det følgende.

\section{Teoretisk grundlag: Entreprenøriel og transformativ læring}

Studiet er baseret på en teoretisk forståelse af entreprenøriel læring, som er kendetegnet ved at se faget som et mulighedsfelt ved at vægte et personligt engagement i læring (autonomi) og skabe læreprocesser, der tillader valgfrihed, ejerskab og personligt ansvar i opgaveløsningen (Bager et al., 2010; Blenker et al., 2012; van Gelderen, 2010; Davidsen, 2014; 2016). Denne teoretiske forståelse er baseret på en fortolkning af sammenhængen mellem entreprenørskab og læring, der peger på, at entreprenøriel læring er organiseret anderledes og skaber andre processer, end såkaldt 'traditionel læring'. Traditionel læring udtrykker en transmissiv opfattelse af læring, der i følge Jonassen og Land handler om at finde den mest effektive måde at kommunikere et indhold på (Jonassen og Land, 1999/2012, s. vii). Det er således effektiv læring af et fast defineret indhold, der er det centrale i traditionel læring, og de nyligt afviklede Demonstrationsskoleprojekter dokumenterer, at denne type læring er almindelig og kommer til udtryk ved, at størstedelen af undervisningen er lærercentreret eller bruges til individuelle og 
træningsprægede opgaver (Hansen \& Bundsgaard, 2016). Denne traditionelle læring er dog ikke kun udtryk for en særlig læringsforståelse, men den afspejler også en særlig samfundsmæssig organisering, som karakteriserer industriel produktion.

Som Gibb (Gibb, 1993, s. 16 ff.) viser, så tegner læring i lyset af entreprenørskab sig i modsætning til den traditionelle læring og industrielt arbejde som en proces, der er kendetegnet ved åbne og komplekse processer (i lighed med ejerskabet af enkeltmandsvirksomheder), som tillader ejerskab, ansvar og mulighed for at planlægge sine egne processer og tage egne valg. I opposition hertil er traditionel læring som nævnt kendetegnet ved lærerstyring, reproduktion og træning $i$ at løse opgaver i overensstemmelse med forudbestemte standarder. Denne type reproduktiv læring minder som angivet om et industrielt lønarbejde og socialiserer til at opfylde prædefinerede mål. I modsætning til det tegner entreprenøriel læring sig som undersøgende og eksperimenterende læreprocesser, der giver eleverne mulighed for selv at planlægge deres arbejdsprocesser og hermed at tage ejerskab til og ansvar for resultatet af dem.

Den selvstændighed, der hermed lægges op til - og som støtter entreprenørielle kompetencer som at tage initiativ, omsætte idéer til handling, se muligheder etc. - styrker også et andet centralt træk ved entreprenørskab, der også er relevant for læring, nemlig autonomi. Som van Gelderen påpeger (van Gelderen, 2010), er autonomi (muligheden for selv at bestemme og at tage egne valg) en drivende faktor i entreprenørskab. Det er det også i læring. Van Gelderen udfolder sammenhængen mellem entreprenørskab, læring og autonomi ved at pege på 'Self-directed learning' som en pædagogisk metode og 'Self Determinations Theory' som en psykologisk motivationsteori, der begge støtter udviklingen af elevens autonomi (van Gelderen, 2010). Begge teorier peger blandt andet på, at selvstændighed og medbestemmelse er centralt for elevernes udvikling af autonomi. Selvstændighed og muligheden for at tage egne valg er altså centralt i en entreprenøriel forståelse af læring.

En anden entreprenørskabsteori, Sara Sarasvathys 'effectuation-teori' (Sarasvathy, 2001; 2008), har peget på evnen til at se muligheder som det afgørende element i entreprenørskab. Denne evne er kendetegnet ved at være 'middel-styret' og ved at stille noget op med de muligheder, der åbner sig i en lokal situation med de ressourcer, der er til rådighed. Den 'middel-orienterede' tilgang står i modsætning til en mål-styret orientering, som er rettet mod at følge en bestemt plan for at nå et mål, der er fastlagt på for- 
hånd. Den målstyrede tilgang tager ikke hensyn til de nye muligheder, der måtte vise sig på vejen til målet.

Læring tegner sig således i lyset af entreprenørskab som en proces, der på mange måder adskiller sig fra det, man forbinder ved traditionel læring, som netop er målstyret ud fra centralt fastlagte læringsmål, og som er organiseret ud fra på forhånd fastlagte års- og lektionsplaner, kommende test og eksamener, og som styres og overvåges af lærere, ledelse, kommune m.m. Der er derfor ikke meget plads i traditionel læring til udviklingen af autonomi, elevernes selvbestemmelse eller selvstyrede læreprocesser, og dermed heller ikke til, at de kan se og forfølge muligheder, tage ansvar for resultater og ejerskab til processer. Skolen styres i stedet ud fra en funktionalitetslogik (Nielsen, 2012), som bevirker, at elevernes læring tilpasses lærernes driftsorienterede planlægning. Dette kommer også til udtryk på flere måder i dette studie, og det er også indfanget af tidligere studier, fx en stor interviewundersøgelse i USA med den sigende titel Freedom to learn, som viser, at eleverne føler sig passiviseret og sat uden for indflydelse af lærernes planlægning og styring: "Many students seem simply to be visitors or tourists in the classroom, moving from one idea to the next without any sense of comprehension, commitment, or involvement" (Rogers and Freiberg, 1969/1994, s. 9).

På baggrund af den entreprenørielle forståelse af læring kan man altså fremhæve betydningen af elevens engagement $\mathrm{i}$ og mulighed for at præge sin egen læring. Dette aspekt har man også været særligt optaget af på Aarhus universitet, hvor en gruppe forskere i 'entrepreneurship-education' har fremhævet det personlige engagement i læring. De har blandt andet med udgangspunkt i Shane \& Venkataraman 'individ-mulighed-nexus'-teori (Shane \& Venkataraman, 2000; Shane, 2003) særligt understreget, at det er et individ, der ser muligheder: "Det vil sige, at muligheder aldrig er muligheder for alle, men muligheder for nogle bestemte individer" (Bager et al., 2010, s. 13). Muligheder er således ifølge gruppen af Aarhus-forskere en effekt af, at et individ har set dem (Bager et al., 2010; Blenker et al., 2012). Dette gælder også for de læringsmuligheder, elever ser i fag. Aarhus-forskerne mener endvidere, at individet ser disse muligheder, fordi de er særligt værdifulde for dem. Dermed peger de på, at det ikke kun er centralt i en entreprenøriel tilgang til læring at skabe rum til elevernes medbestemmelse, men der skal også være plads til deres personlige værdidannelse.

At den personlige værdidannelse er central for læring bekræftes af den pædagogiske retning transformativ læring. Det er her en grundlæggende antagelse, at man ved at overkomme og ændre dominerende værdier og blive 
selv-ledende kan opnå øget motivation og lederskab i eget liv (Mezirow, 1991 og Illeris, 2013). Transformative læreprocesser karakteriseres som processer, hvor den lærendes meningsperspektiver, referencerammer og mentale vaner ændres (Mezirow, 1991. Den centrale antagelse i transformativ læring er, at den lærende kan være blokeret af en bestemt opfattelse af sig selv og verden, som hindrer denne i at opfatte læring som værdifuldt. Derfor opfattes det som væsentligt $i$ et læringsperspektiv at have fokus på såvel den lærendes værdimæssige forståelse af læring som dennes omverdensforståelse.

På baggrund af ovenstående karakteristisk af entreprenøriel og transformativ læring er det antagelsen i dette studie, at man kan styrke elevernes motivation for læring, hvis der lægges mere vægt på deres personlige værdidannelse, hvis de får mere medbestemmelse og flere valgmuligheder. Dette er imidlertid, som beskrevet, vanskeligt at omsætte i praksis i en skole, som er styret af centralt fastlagte mål og en skolepolitik, som aktuelt lægger særdeles stor vægt på målstyret læring og synlige læringsmål (Hattie, 2013; Undervisningsministeriet, 2014; Skovmand, 2016). Derfor er det pragmatiske mål i dette studie at forsøge at skabe en bro mellem de to tilgange ved at udvikle og afprøve undervisningsforløb, der formidler synlige og tydelige læringsmål på en måde, der er meningsfuld for eleverne og skaber mulighed for medbestemmelse og valgmuligheder. Desuden undersøges det, om det har en effekt på elevernes motivation for læring, hvis deres eget værdimæssige engagement i læring bliver en mere eksplicit faktor.

\section{Prototypeudvikling - og de nye læringsmål}

På baggrund af forskningsspørgsmålene blev der udviklet prototyper på to læringsforløb: et danskfagligt litteraturforløb på seks uger for tre 4. klasser (Davidsen et al., 2015a) og et 2-ugers matematikforløb om sandsynlighed for et matematikhold i 8. klasse (Davidsen et al., 2015b). Det centrale i udviklingen af prototyper var formidlingen af læringsmål på en måde, som var meningsfuld for lærere og elever, og som gav mulighed for differentiering. Det var antagelsen, at det var væsentligt, at meningsfuldheden med læringsmålet kunne forstås af eleven, for at denne kunne engagere sig personligt $\mathrm{i}$ det og dermed få sin autonomi i spil, og at differentiering var vigtigt, for at eleven kunne finde sine egne (entreprenørielle) veje til målet.

Formuleringen af meningsfulde læringsmål, der muliggør differentiering, kan i sig selv forekomme at være en vanskelig opgave, men den blev yderligere vanskeliggjort, fordi de nye såkaldte forenklede mål fører til, at 


\begin{tabular}{l|l} 
Målniveau & Prototypens målformuleringer \\
\hline Formål & $\begin{array}{l}\text { Jeg skal lære noget om mig selv, andre mennesker } \\
\text { og den verden, jeg lever i, igennem tekster }\end{array}$ \\
\hline Kompetenceområde/mål & Jeg kan læse tekster \\
\hline $\begin{array}{l}\text { Kompetencemål/ Færdig- } \\
\text { heds- og vidensområde }\end{array}$ & Jeg kan finde en tekst for at finde mere viden \\
\hline $\begin{array}{l}\text { Færdigheds- og vidensmål/ } \\
\text { Læringsmål/tegn på læring }\end{array}$ & $\begin{array}{l}\text { Læs i en fagbog og find tre hjemmesider, hvor } \\
\text { du kan finde svar på dine spørgsmål om Astrid } \\
\text { Lindgren }\end{array}$
\end{tabular}

Figur 1: Målniveauer

læringsmål nu i de ministerielle vejledninger beskrives på otte niveauer på en gang: som 1) kompetenceområde, 2) kompetencemål, 3) færdigheds- og vidensområde, og 4) færdigheds- og vidensmål (som yderligere findes på to trin), 5) læringsmål (fastsættes af læreren) og 6) tegn på læring (fastsættes også af læreren) (Ministeriet for børn, undervisning og ligestilling, 2014a; Undervisningsministeriet et al., 2014). Derudover skal læreren også relatere læringsmålet til 7) formålet for faget og 8) folkeskolens formål. Disse sidste formålsniveauer fremgår ikke tydeligt af ministeriets tekster, men de er centrale, hvis den overordnede mening med de enkelte læringsmål skal frem. Samlet betyder det altså, at det enkelte læringsmål skal formuleres på otte niveauer. Hvis man kun fokuserer på det konkrete læringsmål, læreren opstiller, er der fare for, at såvel læreren som eleven overser det meningsfulde i læringsmålet. Problemet tilspidses af, at der såvel i de nye mål som i vejledningen for målstyret undervisning lægges op til, at læringsmålene er meget specifikke og konkrete, som $\mathrm{fx}$ "Eleven finder oplysninger om $\mathrm{fx}$ Astrid Lindgren ved at søge på hendes egen hjemmeside"2. Et sådant konkret læringsmål angiver ikke, hvad det mere præcist er, eleven skal lære af dette og hvorfor.

Det er derfor en udfordring at opstille læringsmål, som både er tro mod de ministerielle vejledninger, og som også fastholder det meningsfulde i læringsmålene set fra lærernes og elevernes perspektiv, og som også - hvilket er kernen i dette projekt - skaber et mulighedsfelt, som eleverne kan realisere på flere forskellige måder.

I den konkrete udformning af prototypen for dansk var det det faglige mål for dansk i 4 . klasse, der blev arbejdet med i første omgang, og der blev 


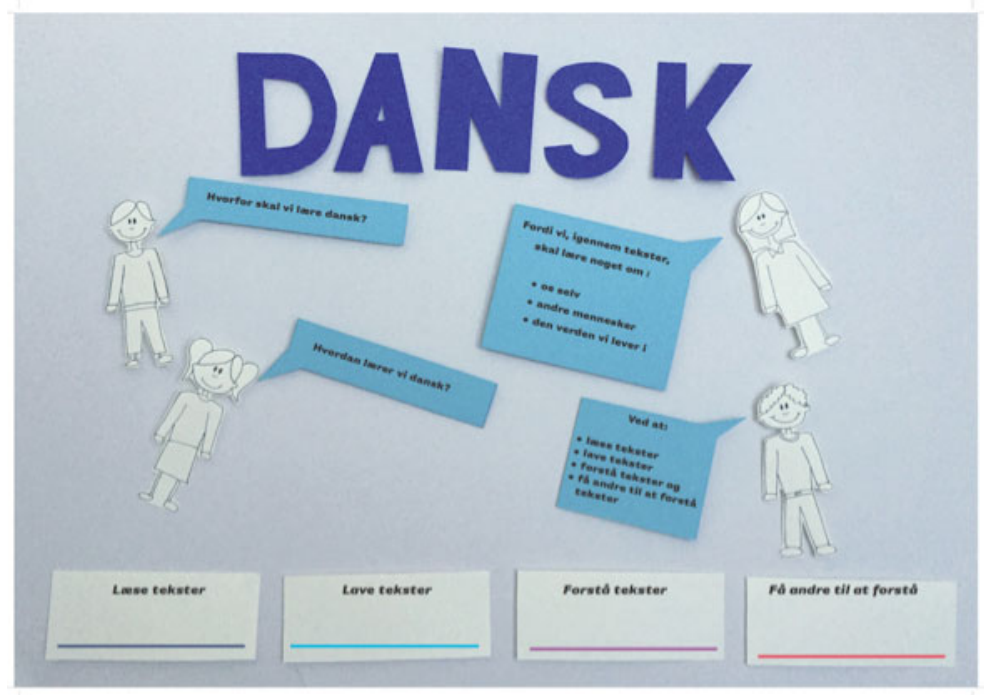

Figur 2: Poster for danskfagets formål og kompetenceområder

især lagt vægt på, at meningen med de faglige mål var tydelig, enkel og elevrettet. Det er et åbent spørgsmål, om denne øvelse i det hele taget er mulig i det nye, komplekse målhierarki, men i figuren nedenfor illustreres det, hvordan de faglige mål blev oversat og reduceret fra ministeriets målniveauer til prototypen

Disse faglige mål blev synliggjort for eleverne i et design, som bestod af en poster, som formidlede formål og kompetenceområder, begge dele formuleret i et elevhenvendt sprog, hvilket fremgår af billedet af posteren (Davidsen et al., 2015a).

Hensigten med designet er tydeliggørelse af formålet med danskfaget for eleverne (Jeg skal lære noget om mig selv, andre mennesker og den verden jeg lever i, igennem tekster) og at gøre kompetenceområderne funktionelle som enkle kompetencemål ('Jeg kan læse tekster', Jeg kan lave tekster', 'Jeg kan forstå tekster', 'Jeg kan få andre til at forstå tekster'). Fremstillet på denne måde bliver danskfaget på såvel hvert klassetrin som i hele folkeskoleforløbet forholdsvis enkelt og meningsfuldt i den forstand, at det hænger sammen og er relateret til elevernes livsverden.

Set fra det entreprenørielle perspektiv ville det være optimalt at fastholde læringsmålene på dette brede kompetenceniveau, da det åbner faget som mulighedsfelt, giver plads til differentiering og elevernes medbestemmelse, men såvel matrixen for de forenklede faglige mål som vejledningen i læringsmålstyret undervisning lægger op til langt mere specifikke lærings- 
mål. Disse specifikke læringsmål begrænser imidlertid elevernes valgmuligheder (man skal lære den og kun denne specifikke ting). De peger ikke på flere læringsveje (kun en), og man taber let udsynet til den overordnede mening, når målet er meget konkret (svækker autonomien).

De specifikke læringsmål åbner derfor ikke i sig selv op for faget som mulighedsfelt, for differentiering og medbestemmelse. Det skaber et behov for en ny måde at formulere læringsmål på, som både peger på differentiering og på fagets formål. I dette studie blev det valgt at relatere læringsmålene til en funktionel meningsfuldhed ved, i overensstemmelse med formålet for folkeskolen, at knytte de specifikke læringsmål til en række typiske arbejdsmåder i elevernes fremtidige jobsammenhænge (vil de arbejde med mennesker, være undersøgende, kreative m.m.). Designmæssigt blev denne funktionalitet repræsenteret som forskellige læringsroller, der udfoldede sig som fire forskelle læringsveje til hvert læringsmål, eller fire forskellige måder, som man kan løse en opgave på:

1) Tale med andre

a) Eleven lærer ved at tale med andre

2) Undersøge verden

a) Eleven lærer ved at undersøge, hvad noget består af

3) Gå på opdagelse i verden

a) Eleven lærer ved at gå ud og undersøge noget i verden

4) Sanse verden

a) Eleven lærer ved at sanse verden.

Disse læringsroller blev omsat til en række læringskort, som angiver et konkret læringsmål (Fx 'Jeg kan finde en tekst for at finde mere viden'), der kan nås gennem fire forskellige opgaver, der var udformet som vist i figur 3 .

Læringskortet angiver desuden (for at skabe sammenhængende meningsfuldhed og overblik) kompetenceområdet (Læse tekster) og Færdigheds- og vidensområdet (Find tekst). Endelig indikerer kortene en simpel struktur i hele forløbet (førlæsning, læsning, efter læsning - af en børnebog af Astrid Lindgren). Hele det 6-ugers forløb, inklusive en valgfri uge til eleverne er desuden beskrevet i form af en drejebog til lærerne (jf. prototypen i Davidsen et al., 2015a).

Designet her viser, at det både er vanskeligt, men dog også muligt, at vise den didaktiske sammenhæng i mål-hierarkiet i de nye Fælles Mål, at skabe meningsfuldhed og differentieringsmuligheder. Det demonstrerer dog også, at det bliver komplekst at fremstille læringsmålene, når alle disse 
formål skal tilgodeses, og det er muligvis for komplekst at få alle disse sammenhænge $\mathrm{i}$ spil på en gang. I hvert fald viste observationerne fra afprøvningen af prototypen, at alle niveauerne (den didaktiske sammenhæng, meningsfuldhed og differentieringsmuligheder) ikke kom i spil i undervisningen. Særligt den didaktiske sammenhæng og formålet med faget (brug af posteren) blev ifølge observationerne ikke italesat. Dette skyldtes også, at afprøvningen var præget af sygdom hos lærerne, men det kan også skyldes, at designet ikke var udformet hensigtsmæssigt. I den efterfølgende udarbejdelse af prototypen til matematik blev der derfor

LESE TEKSTER - FDRLESNING

FIND TEKSTEN

Jeg kan finde en tekst for at finde mere viden

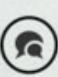
VKLLG ENGAVE

Laringsrolle: Tole med andre

Tal med en bibliotekar om hvilke boger, du kan læse om Astrid Lindgren.

Laringsrolle: Undersege verder

(3) Find en fagbog og find 3 hjemmesider, hvor du kan finde svar pó dine spergsmdi.

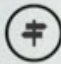

Laringsrolle: Gố pdo opdagelse i verden

(中) 列 lavet dem, og hvorfor de har lavet dem.

Laringsrolle: Sanse verden

Find billeder og film, der fortæller om Astrid Lindgren.

Lase de tekster, jeg har fundet frem til. Skrive ned, optoge

po bând eller tegne det, jeg finder ud of. lagt vægt på at fremhæve lærerens samtaler med eleverne om faglige mål i form af 'matematik-samtaler'. Desuden blev der ikke lavet færdige opgaver til matematikforløbet; de blev i stedet rammesat ud fra en anvendelsesorienteret målformulering i form af tre brugstyper, der er rettet mod fire typer af brugs- og jobkontekster:

1. Matematik, som man bruger til at 'Regne den ud', der er rettet mod dagligdags beregninger og kalkulationer betegnet som 'Hverdag'

2. Matematik, som man bruger som 'Redskab' til forskellige typer af håndværk (typisk geometri) og altså betegnes som 'Håndværk'.

3. Matematik, som man bruger mere abstrakt som et 'sprog' til at beskrive forskellige videnskabelige forhold (typisk funktioner) eller til at beskrive sandsynlighed (typisk statistik), hvilket var rettet mod Science og Journalistik/formidling. 


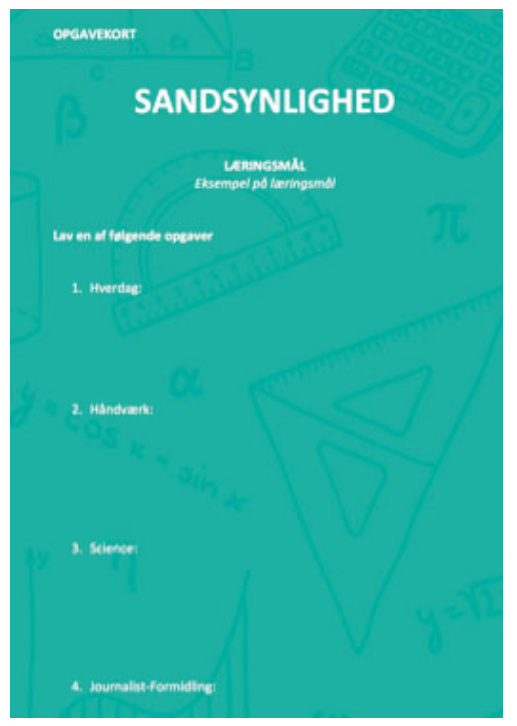

Figur 4: Læringskort til matematik (Davidsen et al., 2015b)

Desværre blev interventionen i matematik så kort, at der ikke var tilstrækkelig mange data i form af observationer til at afgøre, om det nye design havde den intenderede effekt. Selve designet viser dog, at det er muligt at differentiere læringsmål på måder, som giver plads til at se faget som et mulighedsfelt, der aftegner flere læringsveje for eleverne. Desuden viser designet, at der er mange anvendelsesmuligheder i matematik.

Interventionen i dansk peger dog på, at det er nødvendigt at prioritere den faglige samtale mere eksplicit, hvis man ønsker, at differentieringsmulighedernes faglige meningsfuldhed skal udfoldes. Det er tilsyneladende ikke nok at lave en poster eller formulere formål og kompetencemål på en elevhenvendt og meningsfuld måde. Lærerne skal også stilladseres i at tage samtalen med eleven om formål og mål.

\section{Valgmuligheder, motivation og mål}

Udviklingen af protypen viser, at der er mange udfordringer $i$ at koble entreprenøriel læring, personlig meningsfuldhed og læringsmuligheder sammen med arbejdet med læringsmål. Observationerne (18 i alt) fra danskforløbet viste imidlertid forholdsvis entydigt, at det er muligt at skabe differentieringsmuligheder i forhold til læringsmål (i form af læringsroller), og at de motiverede eleverne. Observationerne viste samtidig, som berørt, at læringsmålene ikke kom eksplicit i spil. Det var ikke dem, men læringsrollerne på opgavekortene, der skabte differentieringsmulighederne.

Til observationerne blev der udarbejdet et observationsskema, hvor elevernes udtryk for motivation, deres differentierede tilgang til læring via læringsrollerne og den eksplicitte brug og italesættelse af læringsmål blev noteret. Observationerne blev analyseret ud fra de mønstre, der var genkommende og fremtrædende i elevernes adfærd i forhold til observationspunkterne, og de blev analyseret ud fra projektets forskningsspørgsmål. I og med at læringsmålene ikke kom eksplicit i spil, var det ikke muligt at konkludere noget om deres betydning, hverken om tydeligere læringsmål 
gør det nemmere at differentiere, eller om de motiverer og gør eleverne mere medbestemmende. Det var heller ikke muligt at vurdere effekten af visualiseringen af læringsmål.

Observationerne viste derimod forholdsvis entydigt, at eleverne satte pris på de valgmuligheder, der var i læringskortene (de var engagerede i valgene og glade for at få flere og nye muligheder). Observationerne viste også, at eleverne var tydeligt motiverede af valg af læringsroller/opgaver (de arbejdede vedholdende og fokuserede med opgaverne). Den opfattelse, at det er en udfordring for såkaldt svage elever at arbejde med flere muligheder, blev ikke bekræftet, idet alle eleverne arbejdede koncentreret og vedholdende. Eleverne gav heller ikke op, hvis de mødte modstand i en opgave. I stedet valgte de en anden opgave (med en anden læringsrolle). Valgmuligheder skabte dermed ikke forvirring, men åbnede nye veje. Det er derfor overordnet konklusionen på analysen af observationerne, at differentiering og valgmuligheder (i form af læringsroller) øger elevernes medbestemmelse og motivation for læring.

Som nævnt kom læringsmålene ikke i spil, men differentieringsmulighederne var alligevel virksomme, uden at de eksplicit blev forbundet til læringsmålene. Dette forhold peger på, at læringsmål tilsyneladende ikke er nødvendige for at skabe motivation eller for at rammesætte læring. Det første fund peger således på, at det er muligt at differentiere faget, men at det ikke er nødvendigt at gøre det via læringsmål. Det er udpegningen af flere læringsveje, der er det afgørende, og det er afgørende, at eleverne selv kan vælge mellem vejene.

Det andet fund, at eleverne tilsyneladende fint kunne arbejde motiverede, vedholdende og fokuserede med de forskellige opgaver på læringskortene, uden at de var klar over, hvad læringsmålet var, pegede på, at læringsmål ikke spillede nogen rolle i deres engagement i læreprocessen. Dette gav anledning til en del overvejelser over, hvordan denne iagttagelse skulle fortolkes, da det var overraskede, at læringsmålene tilsyneladende ikke spillede nogen rolle.

En nærmere analyse af observationerne af undervisningen gav en idé om, hvorfor læringsmålene ikke spillede nogen central rolle for elevernes motivation og engagement i læring. Observationerne pegede nemlig på, at læringsmålenes manglende betydning er en effekt af, at læringsmål har en særlig og begrænsende betydning for elevers læring, som står i modsætning til den entreprenørielle tilgang. Observationerne viser nemlig, at eleverne i begyndelsen af projektet henvendte sig til læreren eller vikaren og stillede 
spørgsmål af typen: 'Vil du have, at jeg løser opgaven sådan?', 'Er det rigtigt, hvis jeg gør sådan?', 'Har jeg forstået dette rigtigt?'. Denne elevadfærd viser en spontan orientering mod eksternt formulerede læringsmål, som læreren så at sige administrerer. Eleverne synes at være socialiseret til at være orienteret mod denne form for ekstern bestemmelse af læring, og læringsmål synes at repræsentere denne eksternaliserede læring. Ydermere forstår eleverne disse læringsmål som eksakte læringsmål, der kan vurderes ud fra, om de er rigtige eller forkerte ('Løser jeg denne opgave rigtigt?'). I modsætning til det fungerer læringskortene og de forskellige opgaver som en ramme, der skaber et rum for elevernes læreproces, og som gør det muligt for eleverne at engagere sig i læringen uden at være orienteret mod et eksternt mål. Dette peger altså på, at læringsmål faktisk ikke motiverer elevernes læringsengagement, og slet ikke differentiering og medbestemmelse, i og med at læringsmål opfattes som havende et eksternt, endeligt og eksakt facit.

Denne eksternaliserede opfattelse af læring, som læringsmål tilsyneladende repræsenterer, kan bekræftes af den visuelle refleksion over elevernes læringsværdi, som indgik i dette studie, og af interview med lærerne.

\section{Værdiworkshop}

Som nævnt indledningsvis skulle projektet ikke kun afprøve, om synlige læringsmål kunne fremme, at eleverne så flere muligheder i faget og dermed fremme udviklingen af deres autonomi, men projektet ville også undersøge, om en refleksion over deres personlige læringsværdier kunne støtte deres selvstændige læring. Det blev undersøgt igennem en værdiworkshop, der udfoldede sig som en visuel refleksion over læringsværdier. Værdiworkshoppen var en 2-timers workshop, hvor eleverne lavede en visuel beskrivelse af 'en god skoledag' og 'en mindre god skoledag' ved at udpege fem ting, der skabte 'en god skoledag' og 'en mindre god skoledag'. Desuden angav de med grønne og røde klistermærker, om de mente, at de havde indflydelse på det, der skabte en god/mindre god skoledag (grøn), eller om de ikke havde indflydelse på det (rød).

Værdiworkshoppen resulterede i 48 visuelle collager, som beskrev en god og en mindre god skoledag før og efter interventionen. Collagerne fra før-workshoppen viser, at eleverne tilsyneladende ikke reflekterer over deres læringsværdier. Dette kunne forklares med elevernes alder: at de på grund af deres alder (10-årige) ikke er i stand til at reflektere over deres egne værdier. 


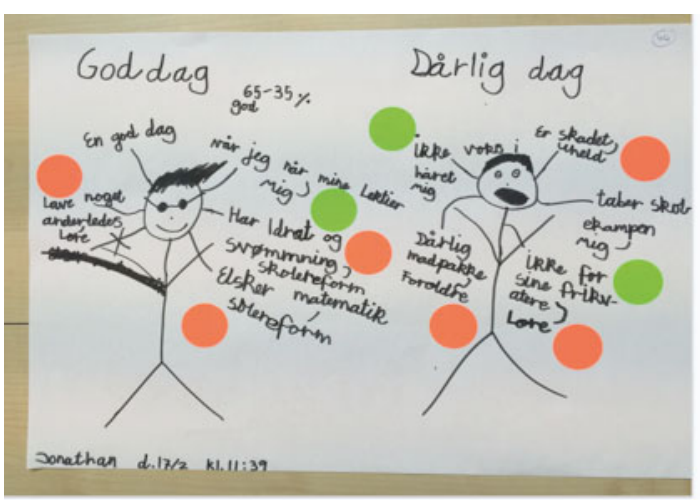

Figur 5: Billede vxrdicollage fra elev i 4 . klasse

Collagerne viser imidlertid, at eleverne godt kan reflektere over, hvad der er værdifuldt for dem i forhold til andre forhold (venner, familie, madpakken, konflikter med andre, vejret og sygdom etc.).

Det forhold, at læring ikke er en faktor, der påvirker, om en dag bliver en god eller mindre god skoledag, blev i stedet fortolket som udtryk for, at eleverne ikke opfatter læring som en værdi, der har noget med dem at gøre personligt. Denne fortolkning blev bestyrket af, at de skolerelaterede elementer, som de udpeger (fx om de har svømning), ikke er nogle, de selv har indflydelse på. Dette blev yderligere fortolket som udtryk for, at det er en lærer eller skoleleder, der bestemmer, og at eleverne generelt opfattede alt, der har noget med fag og faglig læring at gøre, som noget, skolen står for. Det er altså ikke noget, de har indflydelse på, eller som har noget personligt med dem at gøre. Dette mønster er dominerende og kom til udtryk i langt hovedparten af de 48 collagesæt, hvilket er eksemplificeret i denne collage (grøn betyder 'jeg har indflydelse på', mens rød betyder 'jeg har ikke indflydelse på'):

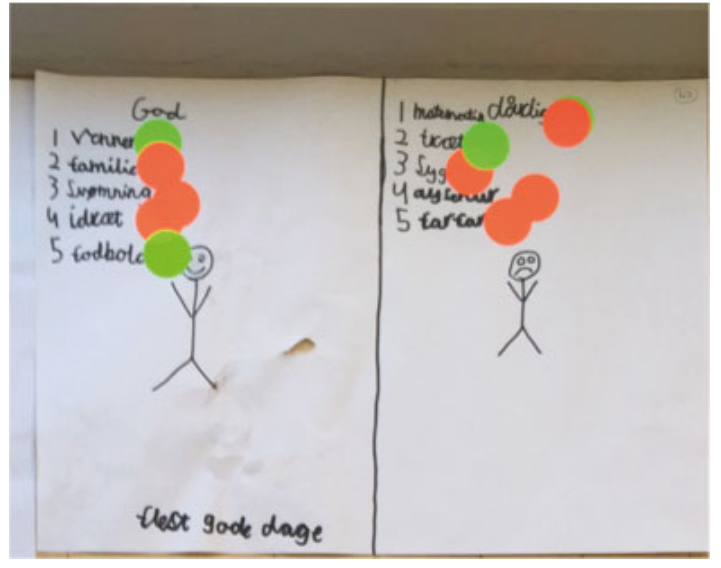

Figur 6: Billede af typisk mønster i før-workshop

Det fremstår som et interessant fund i dette studie, at eleverne ikke reflekterer over læring og ikke har en personlig værdimæssig tilknytning til læring. Elevernes opfattelse af læring som noget aktører uafhængigt af dem styrer, bekræftes endvidere af interview med lærerne, hvor det fremgår, at en god time er en time, som forløber, som læreren har planlagt den. Det vil sige, det er planlægningen og driften af planen, som den foreligger, uafhængigt af elevernes processer, der er det centrale for læreren (jf. den funktionalitetslogik Nielsen (2012) beskriver). Dette bekræfter elevernes opfattelse af læring som noget, de ikke har indflydelse på. 


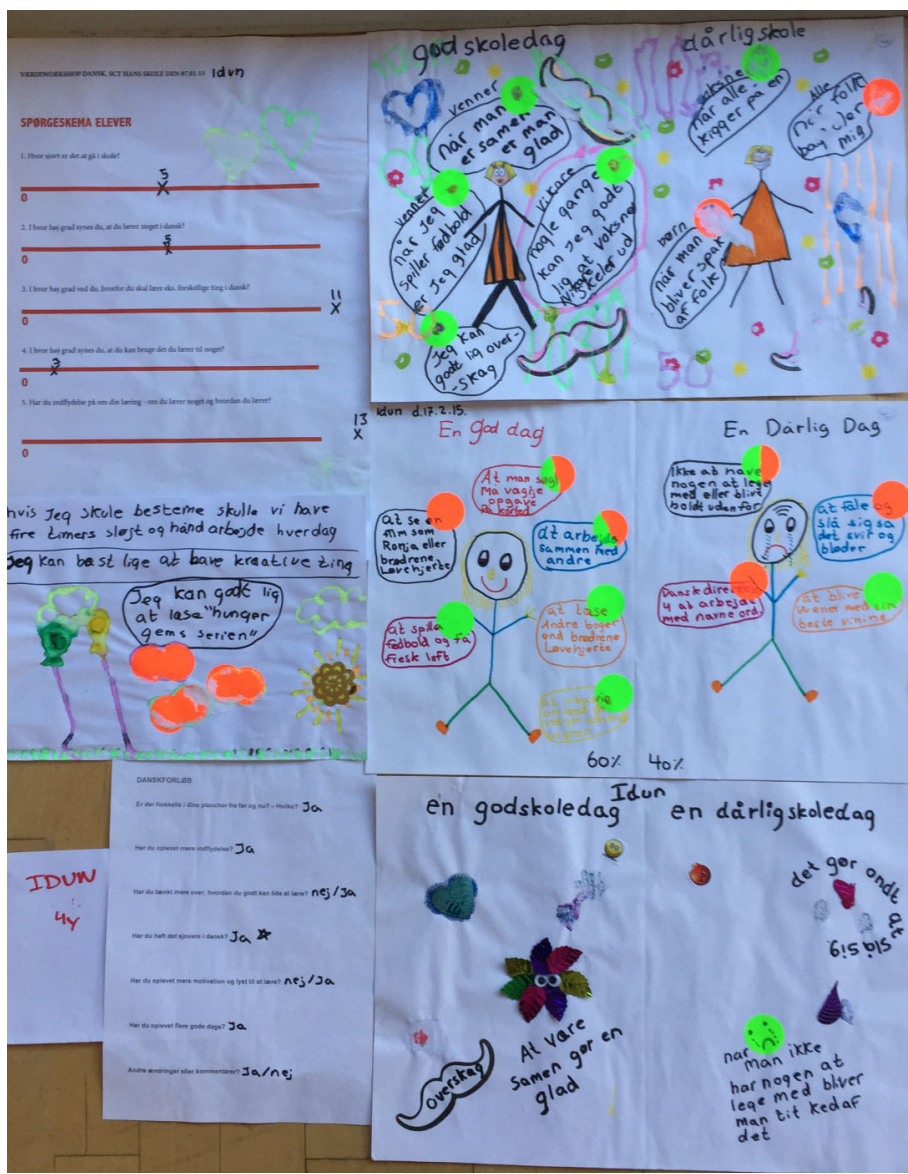

Figur 7: Billede af typisk mønster i efter-workshop

Efter-workshoppen viser imidlertid et andet billede af elevernes engagement i læring og bekræfter, at valgmulighederne i danskforløbet engagerer dem. I efter-workshoppen fylder elementer fra danskforløbet meget i elevernes refleksion over en god og en mindre god skoledag, og særligt fylder valgmulighederne/læringskortene meget. Dette kan naturligvis skyldes, og gør det givetvis også til en vis grad, at danskforløbet har fyldt meget og været et særligt forløb, der har fået en særlig opmærksomhed. Men da størstedelen af collagerne indeholder elementer fra danskforløbet, og de ofte er forholdsvis specifikke, er det en stærk tendens, som illustreres med følgende collage:

Det mest tydelige og mest markante fund i projektet er således, at valgmuligheder giver eleverne mulighed for medbestemmelse, og at det skaber motivation for og personligt engagement i læring, men studiet peger også overraskende på, at elever i udgangspunktet opfatter læring som eksternaliseret, og at læringsmål repræsenterer denne eksternalisering.

\section{Konklusion}

Samlet kom der tre centrale fund ud af studiet, nemlig 1 . at elever ikke reflekterer over læringsværdier, fordi de ikke opfatter faglige læring som noget, der har med dem personligt at gøre, 2. at valgmuligheder motiverer elever, og 3. at læringsmål eksternaliserer elevers læring. 
I forhold til de indledende forskningsspørgsmål kan det bekræftes, at muligheden for differentiering og medbestemmelse motiverer eleverne. Det er imidlertid ikke muligt at af- eller bekræfte, om tydelige læringsmål eller en visuel repræsentation af læringsmål støtter differentiering og medbestemmelse, men studiet peger på, at det gør tydelige læringsmål og visualisering ikke, i og med at læringsmål ikke støtter elevernes personlige motivation for læring. Til gengæld har visualisering som refleksionssprog $\mathrm{i}$ værdiworkshoppene vist sig at være særligt brugbart, da denne åbne form gav adgang til en overraskende indsigt i elevernes frakobling af læring. Det er ikke forventeligt, at studiet ville give adgang til denne indsigt, hvis der var anvendt en mere styret refleksions- eller spørgeform.

Samlet giver fundene anledning til en række fortolkninger på baggrund af projektets teoretiske grundlag og i et Design-Based Research-perspektiv. Her fremhæves to samlende pointer, der angår de generiske sammenhænge mellem læring og motivation i forhold til de tre variable: visualisering, differentiering og medbestemmelse, og som i et Design-Based Research-perspektiv både peger på ny teoretisk indsigt og fastholder, at denne har praktiske konsekvenser.

For det første peger studiet på, at læring udfolder sig som processer, som eleverne spontant engagerer sig $\mathrm{i}$, hvis der er plads til, at de selv kan vælge. Dette bekræfter, at det entreprenørielle mulighedsfelt og den entreprenørielle frihed til at vælge virker motiverende for personligt engagement. Det synes derfor i højere grad at være den mulighedsskabende læringsramme end de styrende læringsmål, der er det centrale for elevernes læringsengagement. Det betyder ikke, at man ikke kan arbejde med læringsmål i skolen, men det er et stort og åbent spørgsmål på hvilken måde, man kan arbejde med dem, så det er hensigtsmæssigt for elevernes læreprocesser, og man skal som lærer være opmærksom på, at målene ikke lukker læringen for eleverne. I et videre teoretisk perspektiv rejser den tilsyneladende positive effekt af processer og den mindre positive effekt af mål spørgsmålet om betydning af processer vs. mål i læring.

For det andet peger studiet på, at faget såvel som læringsmålene kan åbnes op, så der skabes flere læringsmuligheder, mere valgfrihed og mere medbestemmelse, og alle tre forhold bevirker, at eleverne engagerer sig i deres læreprocesser. I dette studie lykkedes det ikke at udvikle en generisk prototype, der kunne differentiere ethvert læringsmål, selvom lærere og elever var udelt begejstrede for de fire læringsroller. De bør dog undersøges nærmere i andre forløb og fag for at blive valideret, og der er også behov for 
at afprøve nye og andre modeller for at fremstille læringsmål på en måde, der åbner mod differentierede læringsmuligheder.

For det tredje peger studiet på, at læring i skolen er præget af en eksternaliseret opfattelse af læring, der gør læring mere til lærernes projekt end elevernes. Dette bekræftes af interview med lærerne, der peger på, at den gode time er en time, som forløber, som læreren har planlagt den. Lærerne giver udtryk for, at de har blik for elevernes læreprocesser, men de oplever et skisma mellem at skulle levere undervisning, der lever op til eksterne læringsmål, og at lave undervisning, der følger elevernes processer. Den mulighed, som blev præsenteret for dem i denne intervention - at skabe læringsrammer, der giver eleverne valgmuligheder - forekommer at være meget ny for dem. Den synes også at skabe en del forvirring, da den ikke passer ind i hverken den ene elle anden model for læring, som lærerne opererer med. Dette peger på, at den entreprenørielle opfattelse af læring, som er kendetegnet ved se faget som et mulighedsfelt, ved at vægte et personligt engagement i læring (autonomi) og skabe læreprocesser, der tillader valgfrihed og medbestemmelse i opgaveløsningen, udfordrer den måde, læring forstås på. Den konflikt, som studiet tog afsæt i, der er mellem såkaldt traditionel lærerstyret læring og entreprenøriel læring, kan tilsyneladende ikke løses eller løsnes op ved at formulere læringsmål på nye måder. Den er mere grundlæggende, men flere valgmuligheder til eleverne er tilsyneladende en forholdsvis enkel måde at skabe mere motivation for læring på.

Det synes i et videre forskningsperspektiv relevant at undersøge elevers personlige motivation for læring nærmere og dens betydning for de læringsmuligheder og læringsvalg, de træffer. Der synes at være forbavsende lidt fokus i skoleforskningen på, hvordan eleverne oplever dette at lære i et personligt og ikke kun fagligt perspektiv, og på hvad der hæmmer og fremmer deres engagement og motivation set $i$ lyset af en tranformativ læringsforståelse. Anden forskning i effekten af entreprenørskabsundervisningen har dog undersøgt, hvordan entreprenørskab som metode påvirker elevernes generelle oplevelse af at gå i skolen, og denne forskning viser, at entreprenørskab som metode har en positiv effekt på elevers oplevelse af skolen (Moberg og Vestergaard, 2014; Moberg et al., 2015).

I et mere vidtrækkende perspektiv spejler, som berørt tidligere, konflikten mellem traditionel lærerstyret og entreprenøriel læring en overordnet samfundsmæssig forskel på et industrielt standardiseret samfund og et entreprenørielt mulighedssøgende samfund (Davidsen og Sørensen, 2015). Denne konflikt komplicereres lige nu yderligere ved at være politisk indspun- 
det $\mathrm{i}$ i en new public management målekultur (styring via måling) og en neoliberal konkurrencepræget 'accountability'-kultur (hvad kan betale sig) (Ward, 2012). I denne idelogiske kamp bliver lærere og elever nemt spændt ud mellem modsatrettede tendenser og krav. Det var en af intentioner i dette studie at finde en pragmatisk og operationel vej midt i en brydningstid, som kunne forbinde krav om mål med ønsket om en mulighedsorienteret didaktik, men fundene i studiet peger på, at målekulturen bør træde i baggrunden til fordel for et fokus på at skabe mangfoldige læringsveje for eleverne.

\section{Referencer}

Amiel, T., \& Reeves, T. (2008). Designbased research and Educational Technology: Rethinking Technology and the Research Agenda. Educational Technology E Society, 11: 29-40.

Bager, L.T., Blenker P., Rasmussen P., Thrane C. (2010). Entreprenørskabsundervisning - proces, refleksion og handling. Aarhus: Aarhus Entrepreneurship Centre, Aarhus Universitet.

Bamberger, J. \& Schön, D.A. (1983). Learning as Reflective Learning as Reflective Conversation with Materials: Notes from Work in Progress. I: Art Education, Volume 36, Issue 2, 1983: 68-73.

Blenker, P., Frederiksen, S.H.,Korsgaard, S.,Müller, S., Neergaard, H., and Thrane, C. (2012). Entrepreneurship as Everyday Practice: Towards a Personalized Pedagogy of Enterprise Education. Industry and Higher Education 26 (6): 417-430

Davidsen, H.M. (2014). Entrepreneurship and learning (www.yedac.eu): 2-22.

Davidsen, H.M. (2016). Meningsfuld læring (to appear), 1-25.

Davidsen, H.M, Hjelm-Hansen C., Sørensen, K.B., og Klitø, N. (2015a). Prototype for dansk.

Davidsen, H.M, Hjelm-Hansen C., Sørensen, K.B., og Klitø, N. (2015b). Prototype for matematik.

Davidsen, H.M., and Sørensen, K.B. (2015). Entrepreneurship as a new learning philosophy. Paper at 3E Conference - ECSB Entrepreneurship Education Conference Lüneburg on 23-24 April 2015: 1-16 http://www.yedac.eu/media/5547/Entrepreneurship-as-a-New-Learning-Philosophy.pdf

Ejersbo, L.R., Engelhardt, R., Frølunde, L., Hanghøj, T., Magnussen, R., and Misfeldt, M. (2008). Balancing Product Design and Theoretical Insights. I: The Handbook of Design Research in Mathematics, Science and Technology Education. Erlbaum, Mahwah, NJ. 149163.

Gelderen, M. van (2010). Autonomy as the guiding aim of entrepreneurship education. Education + Training, Vol. 52. No 8/9, 710-721.

Gibb, A.A. (1993). Enterprise Culture and Education: understanding Enterprise Education and Its Links with Small Business, Entrepreneurship and Wider Educational Goals. International Small Business Journal, Vol. 11 No. 3: 3-32.

Hansen, T.I. \& Bundsgaard (2016). Effektmåling af demonstrationsskoleforsøg. Afrapportering af kvantitative undersøgelser på tværs af de tre demonstrationsskoleprojekter i AUUC-konsortiet.

Hattie, J. (2013). Synlig læring - for lærere. Dafolo.

Illeris, K. (2013). Transformativ læring og identitet. Samfundslitteratur: Frederiksberg.

Jonassen, D.H., Land, S.M. (eds). (2000). Theoretical foundations of learning environments. Lawrence Erlbaum Associates. 
Helle Munkholm Davidsen : Entreprenørskab og læringsmål

Mezirow, J. (1991). Transformative Dimensions of Adult Learning. San Fransisco: Jossey-Bass Publishers.

Ministeriet for børn, undervisning og ligestilling (2014a). Fælles mål for Faget Dansk (http://www.emu.dk/sites/default/files/Dansk\%20-\%20januar\%202016.pdf 20.05.2016)

Ministeriet for børn, undervisning og ligestilling (2014b). Fælles mål for Faget Matematik

Ministeriet for børn, undervisning og ligestilling (2014c). Innovation og entreprenørskab vejledning (http://www.emu.dk/modul/innovation-og-entreprenørskab-vejledning-0. 20.05.2016)

Moberg, K., og Vestergaard, L. (2014). Effektmåling af entreprenørskabsundervisning i Danmark - 2013. Odense: Fonden for Entreprenørskab.

Moberg, K., Fosse, H.B., Hoffman, A., og Jung (2015). Effektmåling af entreprenørskabsundervisning $i$ Danmark - 2014. Odense: Fonden for Entreprenørskab.

Nielsen, L.T. (2012). Teamsamarbejdets dynamiske stabilitet: en kulturhistorisk analyse af læreres læring $i$ team. Aarhus Universitet, Institut for Uddannelse og Pædagogik.

Rogers, C., and Freiberg, H.J. (1996/1994). Freedom to learn. Macmillan College Publishing Company: USA.

Pallasma, J. (2009). The Thinking Hand. Existential and Embodied Wisdom in Architecture. John Wiley \& Sons Ltd.

Sarasvathy, S. (2001). What makes entrepreneurs entrepreneurial? University of Washington School of Business, Washington DC.

Sarasvathy, S.D. (2008). Effectuation: Elements of Entrepreneurial Expertise. Cheltenham, UK: Edward Elgar.

Shane, S., and Venkataraman, S. (2000). The Promise of Entrepreneurship as a Field of Research. Academy of Management Review 25 (1): 217-226.

Shane, S. (2003). A General Theory of Entrepreneurship: The Individual-Opportunity Nexus, Cheltenham: Edward Elgar.

Sibbet, D. (2013). Visual Leaders. New Tools for Visioning, Management E Organization Change. John Wiley \& Sons Inc. Hoboken, New Jersey.

Skovmand, K. (2016). Uden mål og med. Hans Reitzels forlag.

Sørensen, K.B. (2011). When designing emerges into strategies - in an organisation and in individuals. Erhvervs-ph.d.-afhandling, Middelfart Sparekasse \& Designskolen Kolding.

Sørensen, K.B. (2013a). Designing for self-leadership in Proceedings of NORDES 2013: Experiments in design research. Copenhagen: The Royal Danish Academy of Fine Arts, Schools of Architecture, Design and Conservation, s. 163-173.

Sørensen, K.B. (2013b). Transformative services - inviting customers to have artful self-dialogues about money. I: Touchpoint - The Journal of Service Design. Vol. 5 No. 3, 2013.

Undervisningsministeriet i samarbejde med UCC, VIAUC, UC Sjælland og Institut for Uddannelse og Pædagogik (DPU), Aarhus Universitet (2014): Læringsmålstyret undervisning i folkeskolen.

Ward, S. (2012). Neoliberalism and the Global Restructuring of Knowledge and Education. New Yotk: Routledge. 